RESEARCH EDITOR
Harvey Bialy
(New York)
NEWS EDITOR
B.J. Spalding
(New York)
PRODUCTION EDITOR
Mark Goodstein \\ Mark Goodstein
}

BIOИЕCHNOLOGY EDITOR

\section{Susan Hassler}

(New York)

ARTICLES EDITOR

John Hodgson

(London)

SENIOR EDITOR

Stephen M. Edgington

(New York)

\section{EDITORIAL INTERN
Alex Brownstein}

ASSISTANTS

Louise Dughan (London) Michael Ginsberg (New York)

CONTRIBUTING EDITORS

Joseph Alper (Fort Collins, CO); Bernard Dixon (London); Jeffrey L. Fox (Washington, D.C.); Russ Hoyle

(New York); George Kidd (Shorewood, WI);

Kevin McGough (Bronxville, NY);

Robert S. Schehr (Lake Placid, NY);

Mike Ward (Oxford, U.K.)

\section{ART DIRECTOR \\ Lou Pippo \\ ASST. ART DIRECTOR \\ PRESIDENT \& PUBLISHER \\ James Skowrenski \\ VICE PRESIDENT - SALES Marion Delaney \\ ADVERTISING SALES MANAGERS \\ Sande Giaccone (U.S.) \\ Angela Kays (Europe) \\ Marianne S. Ettisch-Mikulka (Classified, U.S.) \\ Julie Skeet (Classified, Europe)} Edna D. Thomas

\section{MARKETING DIRECTOR Barbara Lande \\ MARKETING MANAGERS \\ John D. Whitney (U.S.) \\ Elisabeth Allen (Europe PRODUCTION MANAGER \\ Estelle B. Selzer \\ ASST. PRODUCTION \\ MANAGER \\ PUBLISHING DIRECTOR Renee M. Roberts \\ Andy Sutherland \\ EUROPEAN PUBLISHING MANAGER \\ John Hodgson \\ NEW YORK \\ 65 Bleecker St., New York, NY 10012}

Tel: 1 (212) 477-9600 Fax: 1 (212) 505-1364

Editorial Fax: 1 (212) 254-9493 MCI ID \#: 329-8956

\section{LONDON}

4 Little Essex St., London WC2R 3LF

Tel: (71) 872-0103 Fax: (71) 240-2408

\section{SCIENTIFIC ADVISORY BOARD}

Leroy Hood (chair) University of Washington, Seattle

Ken-ichi Arai DNAX Research Institute

Teruhiko Beppu University of Tokyo

Ronald E. Cape Darwin Molecular Corporation

Jean-Pierre Changeux Institut Pasteur

Mary-Dell Chilton CIBA-Geigy

Nam-Hai Chua $\quad$ Rockefeller University

$\begin{array}{ll}\text { Nam-Hai Chua } & \text { Rockefeller University } \\ \text { Rita R. Colwell } & \text { Maryland Biotechnology Institut }\end{array}$

$\begin{array}{ll}\text { Rita R. Colwell } & \text { Maryland Biotechnology Institute } \\ \text { Arnold Demain } & \text { Massachusetts Institute of Technolog }\end{array}$

$\begin{array}{ll}\text { Arnold Demain } & \text { Massachusetts Institu } \\ \text { J. Lawrence Fox } & \text { Amoco Technology }\end{array}$

David Goeddel Tularik

Morio Ikehara Protein Engineering Research Institute

Ernest Jaworskj Monsanto Company

Kary Mullis Consultant

Victor Nussenzweig New York University Medical Center

$\begin{array}{ll}\text { Victor Nussenzweig } & \text { New York University } \\ \text { Gregory Petsko } & \text { Brandeis University }\end{array}$

$\begin{array}{ll}\text { Gregory Petsko } & \text { Brandeis University } \\ \text { George Poste } & \text { SmithKline Beecham }\end{array}$

George Rose

Carl-Gustaf Rose

Kendall Smith

Washington University

Washington

New York Hospital/Cornel

Medical Center

Yukio Sugino $\quad$ Takeda Chemicals

Marc Van Montagu University of Ghent

Indra K. Vasil

Wataru Yamaya

University of Florid

Seikagaku Kogyo

Palo Alto Institute for
Molecular Medicine

\section{/THE FIRST WORD}

\section{Biotech's Role in Science Education}

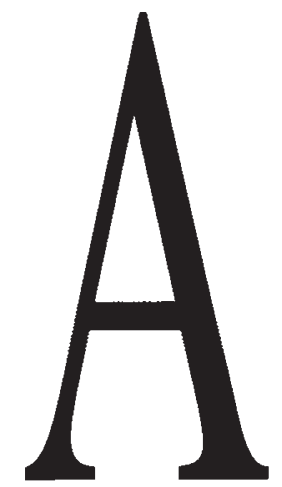

widely quoted set of surveys conducted by the National Science Foundation indicate that a scant 7 percent of U.S. citizens are scientifically literate-in command of a basic vocabulary and grammar of scientific terms and concepts. A subsequent poll undertaken by the National Institutes of Health to learn about public knowledge of biomedical science reveals that the majority of those queried have very vague notions about the definitions of such fundamental terms as DNA and bacteria.

As genetic engineering and molecular biology continue to move out of the laboratory and into the public arena in the form of drugs, therapies, and food products, public understanding of contemporary biology and chemistry will be essential to the public assessment, and one would hope, public acceptance, of the fruits of biotechnology's labor. All current indicators suggest, however, that most Americans will not be in a position to draw informed conclusions about biotech issues, much less work in the industry.

The problems underlying this educational morass are vast. But as Desmond Mascarenhas points out in "A Vital Interest: Science Education and the Biotech Industry," momentum is building in the U.S. to make science education a real priority. Much has been begun, but a great deal more remains to be undertaken, and the biotechnology community can make a significant contribution.

Mascarenhas credits the American Association for the Advancement of Science's Project 2061 and the 1989 National Academy of Science report "Fulfilling the Promise: Biology Education in Our Nation's Schools," with germinating the idea that science education reform and revitalization depend in large part on working scientists, and especially on scientist-teacher partnerships, to create new classroom activities and curricula. He points out that while academic scientists have become involved in such notable education partnership programs as the science and health education partnership at the University of California, San Francisco, industry scientists are largely absent from these ventures, despite the fact that they could bring unique real-world applications to curriculum development. He goes on to argue that if biotechnology wants to build the workforce and the support it will need for its products, it best participate vigorously in attempts to make science education a more prominent part of the cultural landscape.

The problems of scientific literacy are hardly unique to the U.S. In "Europe at Biowork: Challenges and Prospects," Sally Hayward and Martin Griffin discuss the results of a survey they undertook called Project BEMET-Biotechnology in Europe, Manpower, Education, and Training-looking at the current and upcoming employment needs of biotechnology companies on that continent. As in the U.S., the currency of biotechnology in Europe is people and information. However, while there appear to be enough scientists and technologists available in their workforce, Europe's problems seem to be the variable quality of the science education their graduates receive and a dirth of qualified postdocs. Many European companies feel, according to the survey, that the responsbility for these difficulties belongs to the universities. Here again, however, a greater involvement of industry in the planning, development, and implementation of training may help solve the personnel problem. At a broader level, the involvement of European industry in primary and secondary school education and public awareness programs can only be beneficial.

Science is not some peripheral activity of 20th century Western culture. It has defined the world in which we live. In this age of diversity, the languages of science are ones we all have in common. Industry is in the position, not only of funding programs generated by state agencies and academic institutions, but of creating its own vital presence in the educational process. Are industrial scientists prepared to take part?

-SUSAN HASSLER 